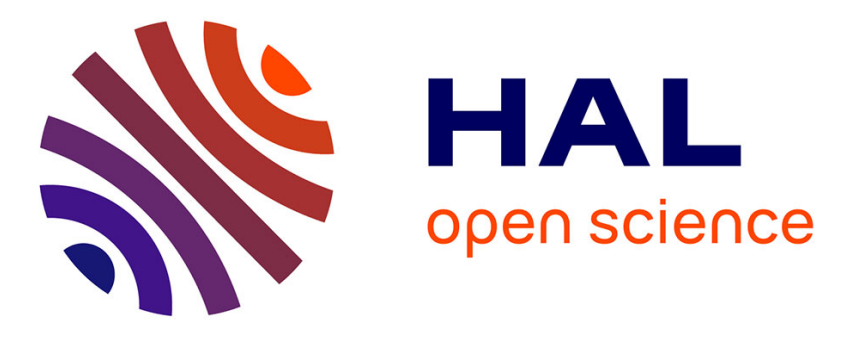

\title{
ExTTF-Based Dyes Absorbing over the Whole Visible Spectrum
}

Pierre-Antoine Bouit, Carmen Villegas, Juan Luis Delgado, Pedro M. Viruela, Rosendo Pou-Amerigo, Enrique Orti, Nazario Martin

\section{- To cite this version:}

Pierre-Antoine Bouit, Carmen Villegas, Juan Luis Delgado, Pedro M. Viruela, Rosendo Pou-Amerigo, et al.. ExTTF-Based Dyes Absorbing over the Whole Visible Spectrum. Organic Letters, 2011, 13 (4), pp.604 - 607. 10.1021/ol102845m . hal-01443302

\section{HAL Id: hal-01443302 https://hal.science/hal-01443302}

Submitted on 17 Jul 2020

HAL is a multi-disciplinary open access archive for the deposit and dissemination of scientific research documents, whether they are published or not. The documents may come from teaching and research institutions in France or abroad, or from public or private research centers.
L'archive ouverte pluridisciplinaire HAL, est destinée au dépôt et à la diffusion de documents scientifiques de niveau recherche, publiés ou non, émanant des établissements d'enseignement et de recherche français ou étrangers, des laboratoires publics ou privés. 


\title{
ExTTF-Based Dyes Absorbing over the Whole Visible Spectrum
}

\author{
Pierre-Antoine Bouit, ${ }^{\ddagger}$ Carmen Villegas, ${ }^{\pi}$ Juan Luis Delgado, ${ }^{\ddagger}, \pi$ \\ Pedro M. Viruela, ${ }^{\S}$ Rosendo Pou-Amérigo, $\$$ Enrique Ortí, ${ }^{\star, \S}$ Nazario

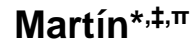

\begin{abstract}
*IMDEA-Nanociencia, Facultad de Ciencias, Módulo C-IX, $3^{a}$ planta, Ciudad Universitaria de Cantoblanco, 28049 Madrid; ${ }^{\pi}$ Departamento de Química Orgánica, Facultad de Ciencias Químicas, Universidad Complutense de Madrid, 28040, Madrid, Spain; ${ }^{\S}$ Instituto de Ciencia Molecular, Universidad de Valencia,46980 Paterna, Spain
\end{abstract}

Email: enrique.orti@uv.es; nazmar@quim.ucm.es

\section{ABSTRACT}

New push-pull dyes featuring $\pi$-extended tetrathiafulvalene (exTTF) as donor group and tricyanofuran (TCF) as acceptor group were synthesized and characterized. Their broad absorption covers the entire visible spectral range and enters the near infrared region. Electrochemistry and theoretical calculations provided an understanding of these these singular electronic properties. The new dyes are appealing candidates as light-harvesters in photovoltaic devices.

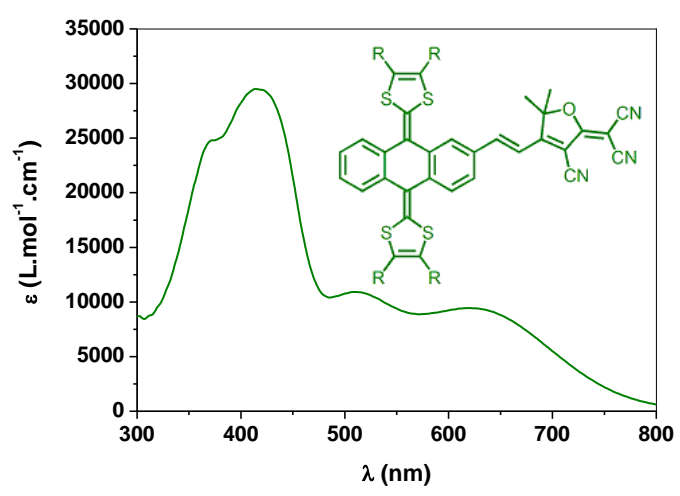

The development of new materials able to transform sunlight into chemical energy or electricity efficiently is currently a major challenge in science. In this regard, organic dyes are an appealing choice as light harvesters provided their synthetic availability, high extinction coefficients and low contamination due to the lack of metal atoms. The recent development of organic and hybrid solar cells, that are able to reach $7 \%$ and $11 \%$ of power conversion efficiency, respectively, has pointed out the crucial need for new organic materials to build up efficient photovoltaic (PV) devices. ${ }^{1}$ For such

1 a) Thompson, B. C.; Frechet, J. M. J. Angew. Chem., Int. Ed. 2008, 47, 58-77. b) Delgado, J. L.; Bouit, P.-A.; Filippone, S.; Herranz, M. A.; Martín, N. Chem. Commun. 2010, 46, 4853-4865. c) Grätzel, M. Inorg. Chem. 2005, 44, 6841-6851. d) Liang, Y.; Xu, Z.; Xia, J.; Tsai, S.-T.; Wu, Y.; Li, G.; Ray, C.; Yu, L. Adv. Mater. 2010, 22, E135-E138. e) Bessho, T.; Yoneda, E.; Yum, J. H.; Guglielmi, M.; Tavernelli, I.; Imai, H.; Rothlisberger, U.; Nazeeruddin, M. K.; Grätzel M. J. Am. Chem. Soc. 2009, 131, 5930-5934. applications, the targeted molecules have to fulfill several chemical and electronic parameters to be integrated into a device. Among them, chemical and thermal stability, processability, and a favorable band offset between the donor and the acceptor (either a fullerene derivative for organic solar cells or $\mathrm{TiO}_{2}$ for dye-sensitized solar cells (DSSCs)) are critical requirements. Furthermore, the capability of the molecule to efficiently collect light in a large part of the solar spectrum, especially in the visible and the near infrared (NIR) regions where the majority of the sunlight intensity is displayed, is an essential issue for these light-harvesting applications. In this context, the synthesis of push-pull chromophores, extensively studied in the field of nonlinear optics (NLO), ${ }^{2}$ recently appeared

2 a) Choa, M. J.; Choia, D. H.; Sullivan, P. A.; Akelaitis, A. J. P.; Dalton, L. R. Prog. Polym. Sci. 2008, 33, 1013-1058. b) Beverina, L.; Fu, J.; Leclercq, A.; Zojer, E.; Pacher, P.; Barlow, S.; Van Stryland, E. W.; Hagan, D. J.; Brédas, J.-L.; Marder, S. R. J. Am. Chem. Soc. 2005, 
as a promising way to build up highly efficient "all organic" and hybrid PV devices. ${ }^{3}$

In this communication, we report the synthesis and the optical and electrochemical properties of new push-pull molecules based on 2-[9-(1,3-dithiol-2-ylidene)anthracen10(9H)-ylidene]-1,3-dithiole (exTTF, see Scheme 1), whose absorption covers the whole visible spectrum and enters in the near-infrared region. Theoretical density functional theory (DFT) calculations were performed to get more insights into the electronic properties of these systems that appear as promising molecules for lightharvesting applications.

ExTTF, a $\pi$-extended analog of tetrathiafulvalene (TTF), is an organic molecule which possesses strong donor ability and singular butterfly shape. ${ }^{4}$ During the last decade, its electronic and geometric features have been used in supramolecular chemistry ${ }^{5}$ as well as in materials science (DSSCs, ${ }^{6}$ charge transfer complexes, ${ }^{7}$ molecular wires, ${ }^{8}$ NLO, ${ }^{9}$ etc). In order to improve the optical absorption properties of the exTTF unit in the visible and NIR range, we have designed new push-pull systems (3a and $\mathbf{3 b}$, Scheme 1) in which the strongly electrondeficient tricyanofuran (TCF) group ${ }^{10}$ has been covalently connected through a $\pi$-conjugated bridge to the exTTF moiety. The attachment of SMe groups to the dithiole rings allows for a fine tuning of the electronic properties of the donor unit.

127, 7282-7283. c) Andreu, R.; Blesa, M. J.; Carrasquer, L.; Garín, J.; Orduna, J.; Villacampa, B.; Alcalá, R.; Casado, J.; Ruiz-Delgado, M. C.; López-Navarrete, J. T.; Allain, M. J. Am. Chem. Soc. 2005, 127, 8835-8845. d) Bouit, P.-A.; Wetzel, G.; Berginc, G.; Toupet, L.; Feneyrou, P.; Bretonnière, Y.; Maury, O.; Andraud, C. Chem. Mater. 2007, 19, 5325-5335. e) Garín, J. ; Orduna, J.; Ignacio Ruperez, J.; Alcala, R.; Villacampa, B.; Sánchez, C.; Martín, N.; .Segura J. L.; Gonzalez, M. Terahedron Lett. 1998, 39, 3577-3580.

3 a) Kroneneberg, N. M.; Deppish, M.; Würthner, F.; Ledemann, H. V. A.; Deing K.; Meerholz, K. Chem. Commun. 2008, 6489-6491. b) Roquet, S.; Cravino, A.; Leriche, P.; Alévêque, O.; Frère, P.; Roncali, J. J. Am. Chem. Soc., 2006,128, 3459-3466. c) Kim, S.; Lee, J. K.; Kang, S. O.; Ko, J.; Yum, J. H.; Fantacci, S.; De Angelis, F.; Di Censo, D.; Nazeeruddin, M. K.; Grätzel M. J. Am. Chem. Soc. 2006, 128, 1670116707.

4 a) Segura, J. L.; Martín, N. Angew. Chem., Int. Ed. 2001, 40, $1372-$ 1409. b) Canevet, D.; Sallé, M.; Zhang, G.; Zhang, D.; Zhub, D. Chem. Commun. 2009, 2245-2269. c) Gorgues, A.; Hudhomme, P.; Sallé, M. Chem. Rev. 2004, 104, 5151-5184. d) Martín, N.; Sánchez, L.; Herranz, M. A.; Illescas, B.; Guldi, D. M. Acc. Chem. Res. 2007, 40, 1015-1024. 5 Isla, H.; Gallego, M.; Pérez, E. M.; Viruela, R.; Ortí, E.; Martín, N. J. Am. Chem. Soc. 2010, 132, 1772-1773. e) Pérez E. M.; Martín, N. Chem. Soc. Rev. 2008, 37, 1512-1519.

6 Wenger, S.; Bouit, P.-A.; Chen, Q.; Teuscher, J.; Di Censo, D.; Humphry-Baker, R.; Moser, J. E.; Delgado, J. L.; Martín, N; Zakeeruddin, S. M.; Grätzel, M. J. Am. Chem. Soc 2010, 132, 51645169.

${ }^{7}$ a) Perepichka, D. F.; Bryce, M. R.; Perepichka, I. F.; Lyubchik, S. B.; Christensen, C. A.; Godbert, N.; Batsanov, A. S.; Levillain, E.; McInnes, E. J. L.; Zhao, J. P. J. Am. Chem. Soc. 2002, 47, $14227-$ 14238.b) Shankara Gayathri, S.; Wielopolski, M.; Pérez, E. M.; Fernández, G.; Sánchez, L.; Viruela, R.; Orti, E.; Guldi, D. M.; .Martín, N. M. Angew. Chem. Int. Ed. 2009, 48, 815-819.

8 Molina-Ontoria, A.; Fernández, G; Wielopolski, M.; Atienza, C.; Sánchez, L.; Gouloumis, A.; Clark, T.; Martín, N.; Guldi, D. M. J. Am. Chem. Soc 2009, 131, 12218-12229.

9 a) Otero, M.; Herranz, M. A.; Seoane, C.; Martín, N.; Garín, J.; Orduna, J.; Alcalá, J.; Villacampa, B. Tetrahedron 2002, 58, 74637475. b) González, M.; Segura, J. L.; Seoane, C.; Martín, N.; Garín, J.; Orduna, J.; Alcalá, R.; Villacampa, B.; Hernández, V.; López Navarrete J. T. J. Org. Chem. 2001, 66, 8872-8882.

10 Liu, S.; Haller, M. A.; Ma, H.; Dalton, L. R.; Jang, S. H.; Jen A. K.Y. Adv. Mater. 2003, 15, 603-607.

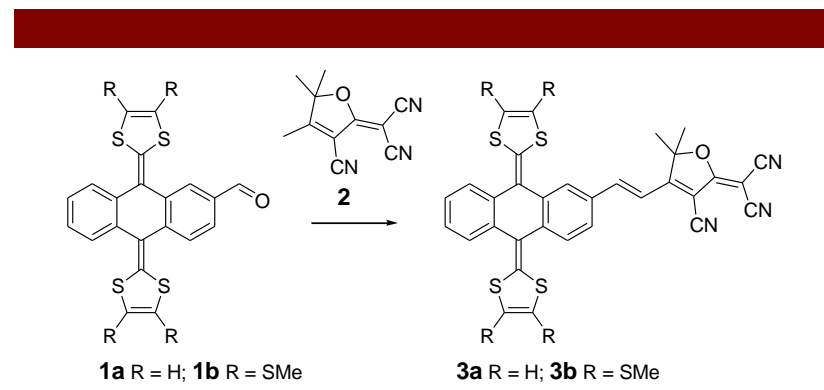

Scheme 1. Synthesis and structure of the new dyes $\mathbf{3 a}$ and $\mathbf{3 b}$.

The synthesis of the two exTTF-based aldehydes 1a and 1b (Scheme 1) was achieved according to an already published multistep synthesis, starting from commercially available 2-(hydroxymethyl)anthraquinone (see the Supporting Information for full synthetic details). ${ }^{11}$ Then, the TCF $^{12}$ moiety $\mathbf{2}$ was introduced by means of microwave-assisted Knoevenagel condensation to afford the targeted molecules $\mathbf{3 a}$ and $\mathbf{3 b}$ in moderate yields (46 and $41 \%$ respectively) as dark green solids. The compounds displayed good solubility in the main organic solvent. In the ${ }^{1} \mathrm{H}$ NMR spectra $\left(300 \mathrm{MHz}, \mathrm{CDCl}_{3}\right)$ of $\mathbf{3 a}$ and $3 \mathbf{b}$, the coupling constant of the vinyl bond $\left({ }^{3} J_{\mathrm{HH}}=16\right.$ $\mathrm{Hz}$, see SI) proved the trans character of the oligoenic backbone.

Figure 1 displays the minimum-energy molecular geometry computed for 3a at the B3LYP/6-31G* level (see the SI for computational details). As expected, the exTTF fragment possesses the typical concave saddle-like shape, ${ }^{13}$ in which the central ring of the anthracene unit folds up in a boat conformation and the dithiole rings are tilted down. As shown in Figure 1, the TCF moiety is coplanar with the ethylene bridge and the aromatic ring of the anthracene skeleton to which it is attached. This result suggests that an efficient $\pi$-conjugation can operate between the donor and acceptor units in these molecules.

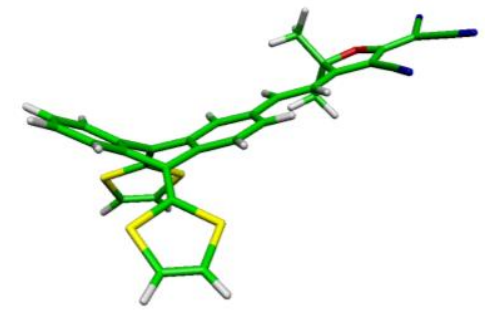

Figure 1. Minimum-energy B3LYP/6-31G** structure of 3a.

${ }^{11}$ Martín, N.; Pérez, I.; Sánchez, L.; Seoane, C. J. Org. Chem. 1997, 62, 5690-5695.

12 Melikian, G; Rouessac, F. P.; Alexandre, C. Synth. Commun. 1995, 25, 3045-3051.

13 a) Martín, N.; Sánchez, L.; Seoane, C.; Ortí, E.; Viruela, P. M.; Viruela, R. J. Org. Chem. 1998, 63, 1268-1279. b) Díaz, M. C.; Illescas, B. M.; Martín, N.; Viruela, R.; Viruela, P. M.; Ortí, E.; Brede, O.; Zilbermann, I.; Guldi, D. M. Chem. Eur. J. 2004, 10, 2067-2077. 
Figure 2 shows the atomic orbital (AO) composition of the highest-occupied (HOMO-2 to HOMO) and lowestunoccupied (LUMO and LUMO+1) molecular orbitals of 3a. The HOMO $(-5.17 \mathrm{eV})$ and HOMO-1 $(-5.76 \mathrm{eV})$ are localized on the electron-donor exTTF unit and are calculated at lower energies than the HOMO $(-4.64 \mathrm{eV})$ and HOMO-1 $(-5.22 \mathrm{eV})$ of the exTTF molecule. In contrast, the LUMO $(-3.22 \mathrm{eV})$ spreads over the electronacceptor TCF unit with a large participation of the ethylene bridge and is obtained at lower energies than the LUMO of TCF $(-2.86 \mathrm{eV})$. Therefore, compound 3a presents a small HOMO-LUMO energy gap of $1.95 \mathrm{eV}$ and low-energy charge-transfer (CT) absorption bands are to be expected in the electronic spectrum. The electronic communication between the donor and acceptor units is evidenced by the shift to lower energies of the HOMOs and by the charge transfer of $0.20 \mathrm{e}$ that takes place from the exTTF unit to the TCF moiety.

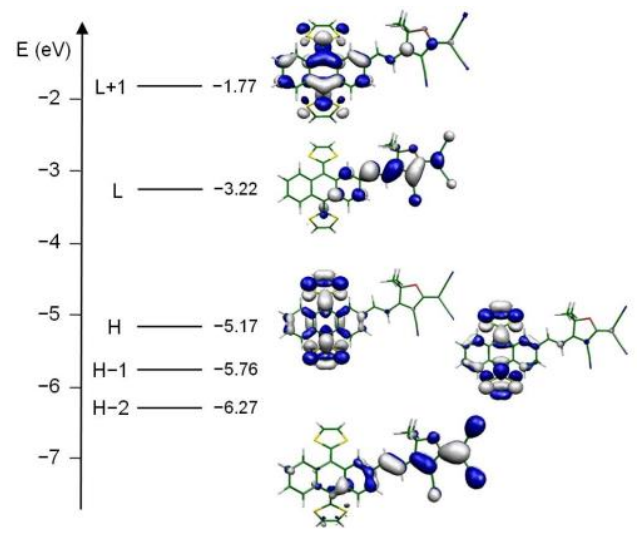

Figure 2. Electron density contours $\left(0.03 \mathrm{e} \mathrm{bohr}^{-3}\right)$ and orbital energies calculated for the HOMOs and LUMOs of $\mathbf{3 a}$ at the B3LYP/6-31G** level. H and L denote HOMO and LUMO, respectively.

The redox properties of $\mathbf{3 a}$ and $\mathbf{3 b}$ were examined by cyclic voltammetry (CV) and compared with those of exTTF and TCF (Figure 3, Table 1, and Table S1). 3a undergoes a quasi-reversible, two-electron oxidation at $\mathrm{E}^{\circ}{ }_{\text {ox }}=0.25 \mathrm{~V}$ vs. $\mathrm{Ag} / \mathrm{AgNO}_{3}$, which is slightly influenced by the SMe substituents on the dithiole rings (3b: $0.35 \mathrm{~V})$. The oxidation process is assigned to the oxidation of the exTTF fragment, by comparison with the reference exTTF compound $\left(\mathrm{E}_{\mathrm{ox}}{ }^{1 / 2}=0.24 \mathrm{~V}\right)$. No appreciable impact on the oxidation of the exTTF unit is therefore detected despite the presence of the electron-acceptor TCF unit and in contrast with the lower energy predicted for the HOMO of 3a. Using Koopmans' theorem, a lower-energy HOMO would lead to a more positive oxidation potential. The reason for this apparent discrepancy between experiment and theory is that Koopmans' theorem is a one-electron approach and does not apply to the oxidation process of $\mathbf{3}$, which involves two electrons. $\mathbf{3 a}$ and $\mathbf{3 b}$ also undergo a non-reversible one electron reduction at $\mathrm{E}_{\mathrm{red}}=$ $\sim 0.55 \mathrm{~V}$, which is strongly shifted compared to the reduction of $2\left(\mathrm{E}_{\mathrm{red}}=-1.17 \mathrm{~V}\right)$. The anodic shift is in agreement with the lower energy predicted for the LUMO of $\mathbf{3 a}$ and is due to the great conjugation introduced by the ethylene bridge (Figure 2).

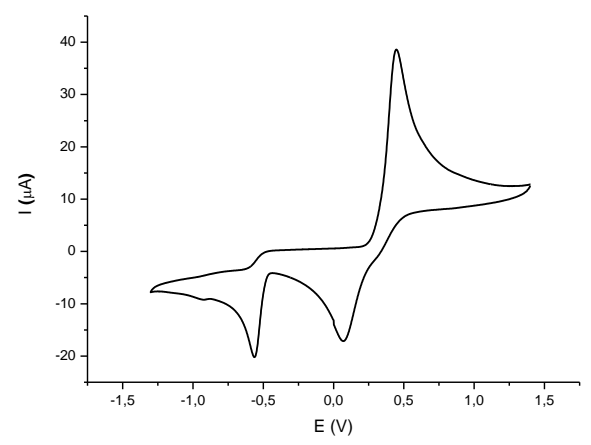

Figure 3. $\mathrm{CV}$ trace obtained for $3 \mathrm{a}\left(\mathrm{CH}_{3} \mathrm{CN}, 0.1 \mathrm{M}\right.$ $\mathrm{Bu}_{4} \mathrm{NClO}_{4}, \mathrm{v}=100 \mathrm{mV} \cdot \mathrm{s}^{-1}, \mathrm{~V}$ vs. $\left.\mathrm{Ag} / \mathrm{AgNO}_{3}\right)$.

The absorption properties of the dyes were measured in diluted dichloromethane solution (Table 1 and Figure 4). 3a and $\mathbf{3 b}$ present a broad absorption covering the whole visible and entering the NIR, which can be divided into three main absorption bands. In first approximation, the lowest-energy band with absorption maxima at 635 (3a) and $628 \mathrm{~nm}(\mathbf{3 b})$ was attributed to a charge transfer (CT) band, as this band appears with the insertion of the TCF acceptor unit and it displays the typical shape of a CT transition (broad absorption, low intensity). This band, situated in the red part of the visible, indicates a small HOMO-LUMO energy gap in these dyes. The optical gap $\left(E_{\mathrm{g}}{ }^{\text {opt}}\right)$ obtained from the absorption onset recorded about $800 \mathrm{~nm}$ is $\sim 1.55 \mathrm{eV}$. The second band around $500 \mathrm{~nm}$ is also associated to the insertion of the TCF unit and presents a small red shift in passing from $\mathbf{3 a}$ to $\mathbf{3 b}$. Surprisingly for a polar compound, these transitions are weakly solvatochromic without clear trend depending on the solvent polarity (see Figure S7 and S8). ${ }^{14}$ One reason might be that the two transitions are overlapping and might have opposite solvatochromic behavior. It is important to remind that the absence of intermolecular interactions in exTTF derivatives ${ }^{6}$ ruled out the possibility of solvent induced aggregation. Finally, a third and more intense band is observed at $420 \mathrm{~nm}$. This band is in principle attributed to an electronic transition within the exTTF unit which presents an intense absorption at 428 nm. ${ }^{15}$ These absorption properties, with exctinction coefficient superior to $5000 \mathrm{~L} \cdot \mathrm{mol}^{-1} \cdot \mathrm{cm}^{-1}$ from 300 to 700 $\mathrm{nm}$, make compounds $\mathbf{3 a}$ and $\mathbf{3 b}$ very interesting as materials for light-harvesting applications.

14 C. Reichardt Chem. Rev. 1994, 94, 2319-2358.

15 Guldi, D. M.; Sánchez, L.; Martín, N. J. Phys. Chem. B 2001, 105 , 7139-7144. 
Table 1. Electrochemical and optical data for $\mathbf{3 a}$ and $\mathbf{3 b}$

\begin{tabular}{|c|c|c|c|c|c|}
\hline compound & $\mathrm{E}_{\mathrm{ox}}{ }^{1 / 2}(\mathrm{~V})^{a}$ & $E_{\mathrm{red}}(\mathrm{V})^{a}$ & $E_{\mathrm{g}}{ }^{\mathrm{cv}}(\mathrm{eV})^{b}$ & $\lambda_{\max }(\mathrm{nm})^{c}$ & $\varepsilon\left(\mathrm{L} \cdot \mathrm{mol}^{-1} \cdot \mathrm{cm}^{-1}\right)^{c}$ \\
\hline 3a & 0.25 & -0.56 & 0.81 & 635 & 8800 \\
\hline 3b & 0.35 & -0.55 & 0.90 & 628 & 9400 \\
\hline
\end{tabular}

${ }^{a}$ Measured by $\mathrm{CV}\left(\mathrm{CH}_{3} \mathrm{CN}, 0.1 \mathrm{M} \mathrm{Bu}_{4} \mathrm{ClO}_{4}, \mathrm{v}=100 \mathrm{mV} \mathrm{s}^{-1}, \mathrm{~V}\right.$ vs. $\left.\mathrm{Ag} / \mathrm{AgNO}_{3}\right) .{ }^{b}$ Electrochemical energy gap determined as $E_{\mathrm{ox}}-E_{\text {red. }}{ }^{c} \mathrm{Measured} \mathrm{in}$ DCM, $10^{-5} \mathrm{~mol} \mathrm{~L}^{-1}$.

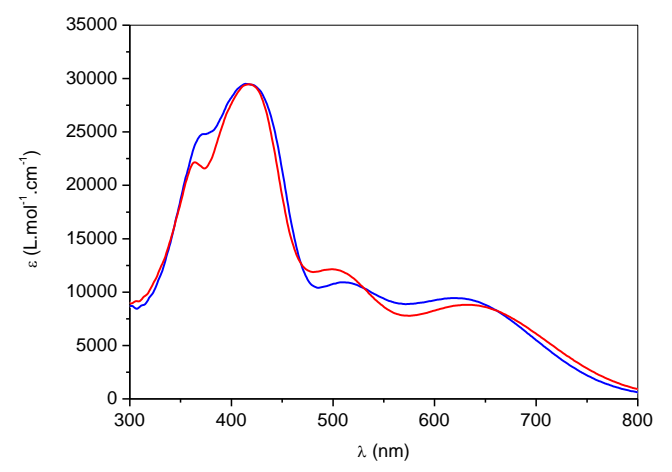

Figure 4. Absorption spectra of 3a (red) and $\mathbf{3 b}$ (blue) recorded in dichloromethane at room temperature.

To investigate the nature of the electronic transitions that give rise to the absorption bands observed in the electronic spectra, the lowest-energy singlet excited states $\left(\mathrm{S}_{\mathrm{n}}\right)$ were calculated for $\mathbf{3 a}$ using the time-dependent DFT (TDDFT). ${ }^{16}$ PBE0/6-31G** calculations predict that the absorption bands observed for $\mathbf{3 a}$ at $635 \mathrm{~nm}(1.95 \mathrm{eV})$ and $499 \mathrm{~nm}(2.48 \mathrm{eV})$ are due to electronic transitions to the first two excited singlets, $\mathrm{S}_{1}$ and $\mathrm{S}_{2}$, calculated at 1.75 and $2.33 \mathrm{eV}$. These states originate in the $\mathrm{HOMO} \rightarrow$ LUMO and HOMO $-1 \rightarrow$ LUMO monoexcitations, respectively, and imply an electron density transfer from the exTTF moiety, where the HOMO and HOMO-1 reside, to the TCF unit, where the LUMO is mainly located (see Figure 2). Calculations therefore confirm the CT nature of the two low-energy absorption bands of compounds 3 . The medium intensities observed for these bands are in agreement with the oscillator strengths calculated for $\mathrm{S}_{1}$ and $\mathrm{S}_{2}(f=0.17$ and 0.32 , respectively), and are due to the planar structure of the conjugated ethylene bridge that allows for a significant overlap between the HOMO/HOMO-1 and the LUMO.

The intense absorption band observed at $418 \mathrm{~nm}$ is assigned to electronic transitions to the $\mathrm{S}_{3}$ and $\mathrm{S}_{4}$ states that are computed close in energy at $2.99 \mathrm{eV}(415 \mathrm{~nm})$

16 Vertical transitions to the lowest-energy electronic states were calculated at both the B3LYP/6-31G** and PBE0/6-31G** levels. Both calculation levels lead to identical descriptions of the electronic transitions in terms of monoelectronic excitations, but the PBE0 functional provides slightly higher excitation energies (see Table S2). and $3.12 \mathrm{eV}(398 \mathrm{~nm})$, respectively. The $\mathrm{S}_{3}$ state results from the HOMO-2 $\rightarrow$ LUMO excitation, that mainly implies the TCF moiety and the ethylene bridge (Figure $2)$, and is calculated to be very intense $(f=0.92)$. In contrast, the $\mathrm{S}_{4}$ state originates in the $\mathrm{HOMO} \rightarrow \mathrm{LUMO}+1$ excitation centered on the exTTF moiety and has a lower intensity $(f=0.28)$. Therefore, the intense band at $418 \mathrm{~nm}$ mainly results from the excitation of the TCF moiety. Excitation of the exTTF fragment contributes in a lower degree to this absorption band.

In summary, two new push-pull molecules associating $\pi$-extended TTF as electron donor and tricyanofuran as electron acceptor have been synthesized. The new chromophores possess a broad optical absorption covering the visible spectrum from 300 to $800 \mathrm{~nm}$. The broad absorption is due to the efficient electronic connection between the donor and acceptor units through the conjugated ethylene bridge, which determines the appearance of medium-intensity charge-transfer bands extending into the near-infrared region. These low bandgap molecules may be used as new molecular materials in the field of photovoltaics. ${ }^{17}$ Molecular engineering is currently in progress in the laboratory in order to take advantage of the outstanding optical properties of these compounds in molecular bulk heterojunction devices ${ }^{18}$ or as photosensitizers grafted on $\mathrm{TiO}_{2}$ in DSSCs.

Acknowledgments. This work has been supported by the European Science Foundation (SOHYD, MAT200628170-E), the MICINN of Spain (CT2008-00795, CTQ2009-08790, and Consolider-Ingenio CSD200700010 on Molecular Nanoscience), and Comunidad de Madrid (MADRISOLAR-2, S2009/PPQ-1533). P.A.B. thanks IMDEA-Nanociencia for a postdoctoral research grant. J.L.D. thanks the MICINN of Spain for a Ramón y Cajal Fellowship co-financed by the EU Social Funds.

Supporting Information Available Synthetic procedure, complete characterizations, and computational details. This material is available free of charge via the Internet at http://pubs.acs.org.

\footnotetext{
17 a) Silvestri, F.; Irwin, M. D.; Beverina, L.; Facchetti, A.; Pagani, G. A.; Marks T. J. J. Am. Chem. Soc 2009, 130, 17640-17641. b) Rousseau, T.; Cravino, A.; Bura, T.; Ulrich, G.; Ziessel R.; Roncali, J. Chem. Commun. 2009, 1673-1675.

18 a) Roncali, J. Acc. Chem. Res. 2009, 42, 1719-1730. b) Bouit, P.-A.; Rauh, D.; Neugebauer, S.; Delgado, J. L.; Di Piazza, E.; Rigaut, S.; Maury, O.; Andraud, C.; Dyakonov V.; Martín, N. Org. Lett, 2009, 11, 4806-4809.
} 